Concepções filosóficas e representações do feminino: Subsídios para uma hermenêutica crítica da tradição filosófica

Philosophical Conceptions and Representations of the Feminine: Notes towards a Critical Hermeneutics of the Philosophical Tradition

Conceptions philosophiques et représentation du feminine: apports pour une herméneutique critique de la tradition philosophique

Fernanda Henriques

(2) OpenEdition

Journals

Edição electrónica

URL: http://journals.openedition.org/rccs/3661

DOI: $10.4000 /$ rccs.3661

ISSN: 2182-7435

\title{
Editora
}

Centro de Estudos Sociais da Universidade de Coimbra

Edição impressa

Data de publição: 1 junho 2010

Paginação: 11-28

ISSN: 0254-1106

Refêrencia eletrónica

Fernanda Henriques, « Concepções filosóficas e representações do feminino: Subsídios para uma hermenêutica crítica da tradição filosófica », Revista Crítica de Ciências Sociais [Online], 89 | 2010, posto online no dia 01 outubro 2012, consultado o 10 dezembro 2020. URL : http://journals.openedition.org/ rccs/3661 ; DOI : https://doi.org/10.4000/rccs.3661

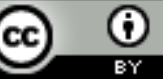




\section{Concepções filosóficas e representações do feminino: Subsídios para uma hermenêutica crítica da tradição filosófica}

A partir da interpretação de uma já vasta bibliografia que tem desocultado o papel das mulheres ao longo da nossa cultura, este trabalho pretende desconstruir a ideia comum de que o domínio masculino foi sempre pacífica e universalmente aceite. Nesse sentido, pretende chamar a atenção para que na Grécia, uma origem conceptual da nossa tradição, paralelamente ao pensamento canónico, dominante, houve ruídos significativos que manifestam outros modos de pensar e representar o feminino, mostrando a necessidade de re-significar a nossa recepção da tradição clássica.

Palavras-chave: feminismo; filosofia; mulheres; tradição clássica.

O que é desejável tem de se tornar possível.

Adela Cortina

A nossa herança é o nosso poder.

Judy CHICAgo

Este texto releva da convicção radicada em Aristóteles não só que o ser se diz de muitas maneiras, como ele afirmou explicitamente, mas também e, porventura, principalmente, que o ser se diz em conjunto, numa polifonia de vozes, umas mais harmónicas e próximas, outras mais dissonantes e afastadas, mas todas, igualmente, imprescindíveis. Esta última convicção - a da imprescindibilidade de todas as vozes para explicitar o sentido da realidade - alimentará sempre a minha crítica e devo-a a Paul Ricoeur e à sua lapidar ideia de que o campo hermenêutico é constitutivamente fragmentado, sem possibilidade de nenhuma mediação perfeita, estando, por isso, a racionalidade humana condenada ao conflito das interpretações que representa a última fronteira de uma racionalidade finita, simplesmente humana. 
Por isso, é sob a custódia de Paul Ricoeur que empreendo a escrita de qualquer texto no horizonte de uma dialectique à synthèse ajournée, ou seja, sabendo que ele vai ser devedor de muitos outros textos, que escrever é, na sua essência, intertextualizar, que a urdidura textual que produzir é constitutivamente inacabada e que haverá outros textos que se oporão ao meu e irão originar novos textos permitindo o conjunto de todos eles uma visão mais esclarecedora, mais profunda e mais verdadeira da realidade.

O objectivo do trabalho é articular o pensar filosófico com a conceptualização do feminino, destacando alguns aspectos dessa articulação na cultura grega, no momento do aparecimento da filosofia, não por qualquer vício historicista de começar no princípio, mas apenas por reconhecer que, no chamado Mundo Ocidental, a Grécia é um momento instaurador e, no âmbito filosófico, representa a própria fundação de um modo de pensar diferente, abrindo um espaço teórico completamente novo, seja como for que se interprete a passagem do mito ao logos.

No caso vertente, das concepções filosóficas e das representações do feminino, parece ser pacífico afirmar que recebemos da Grécia uma discriminação antropológica fundadora, uma espécie de estereótipo arquetípico, que levou a pensar o feminino como derivado e, consequentemente, as mulheres como o segundo sexo, ao longo de toda a tradição ocidental. Mas parece ser igualmente pacífico reconhecer que também veio da Grécia a conceptualização do feminino e das mulheres no respeitante, por exemplo, à configuração da força, da coragem e da convicção, como é o caso de Antígona, ou da possibilidade das filósofas-rainhas, como é proposto em a República, de Platão. Neste contexto, não parece racionalmente legítimo considerar-se apenas que na Grécia as mulheres estavam confinadas ao gineceu, não podiam entrar na vida pública a não ser para algumas festas religiosas e eram conceptualmente aproximadas dos escravos e das crianças, porque, embora cada uma destas coisas tenha ocorrido, parece ter havido também outras ocorrências que contrariam a universalidade do desrespeito pelo feminino e pelas mulheres. Nessa medida, a finalidade última deste texto é desnaturalizar a ideia de que a dominação masculina foi sempre pacificamente aceite.

Não sendo eu helenista, nem especialista de Filosofia Antiga, este trabalho vai explorar as linhas de investigação desenvolvidas sobre a problemática em causa e, com base no estado da arte, propor algumas interpretações. 


\section{Sentido e legitimidade da busca de uma conceptualização do feminino e das mulheres}

No quadro do estabelecimento do sentido e da legitimidade deste trabalho, do ponto de vista feminista, cabe perguntar:

- Vale a pena um mergulhar na história da filosofia ou na das ideias culturais em busca de raízes?

- Será possível e útil fazê-lo, ou o androcentrismo da linguagem vai ter um efeito perverso nesta pesquisa?

Obviamente, a existência deste texto representa uma resposta afirmativa a qualquer das duas interrogações; todavia, não será despiciendo mostrar que ele é filosoficamente consistente e militantemente útil. Para isso, vou tentar explicitar o que me separa de posições que defendem a alteridade absoluta do feminino, como é o caso de Luce Irigaray para quem um projecto como este de tentar re-significar alguns passos da tradição não só pode ser irrelevante como pode ser mesmo prejudicial, "[porque] a tarefa não é elaborar uma nova teoria de que a mulher seria o sujeito ou o objecto, mas travar a própria maquinaria teórica, suspender a sua pretensão à produção de uma verdade e de um sentido demasiado unívocos" (Irigaray, 2003: 51). Trata-se, então, de encontrar na maquinaria teórica recursos operacionalizáveis. Fá-lo-ei através da hermenêutica de Gadamer, segundo o que Ricoeur traduz como eficácia do trabalho da história, como forma de caracterizar a perspectiva gadameriana sobre o tema da consciência histórica, que faz dela, simultaneamente, condição de possibilidade e de constrangimento do modo como interpretamos a realidade. Para Gadamer, ter sentido histórico é medir o nosso pensamento com o nosso horizonte histórico, assumindo a nossa consciência histórica, ou seja, é darmos conta de nós dentro do desenrolar de um processo que nos contextualiza e, de alguma maneira, nos forma. Por isso, é nosso destino trabalharmos a história que nos trabalha.

Gadamer chama preconceito ao resultado do trabalho da história sobre nós, pretendendo designar aquilo que se poderia caracterizar como esquemas de significação trans-subjectivos, e que funcionam como princípios de leitura da realidade. Tais esquemas de significação representam o que, em linguagem de Kant, se pode designar como os óculos constitutivos da humanidade que a confinam a um irredutível Standpunkt, que, contudo, não é um relativismo e sim uma consequência inevitável da finitude humana. Conhecemos a realidade e intervimos nela através de condicionamentos inerentes a sermos humanos: a nossa inserção histórica, social, e cultural e o facto de termos um corpo fazem do discurso humano, qualquer que ele seja, uma interpretação mais ou menos validada pelas premissas e axiomas em que se 
inscreve. Esta perspectiva opõe-se ao padrão epistemológico ocidental que instaurou as ideias de neutralidade, universalidade e objectividade como apanágios da verdade e do valor do saber, assentes na ideia de uma razão pura, transparente e asséptica que produzisse e fornecesse um conhecimento sem mácula ou impressão digital, querendo denunciar que tal posição escamoteia quase sempre a ideologia do homem branco e louro e que só parece ser universalmente aceite porque é ainda esse homem branco e louro quem detém a dominância da emissão discursiva.

Entre muitas perspectivas críticas, também a racionalidade hermenêutica põe em causa esta espécie de positivismo epistemológico, ao mostrar que se fala sempre de um lugar humano e cultural e que estamos irremediavelmente ligados ao ser ou à realidade que procuramos entender, pelo que "não podemos saber o todo, porque estamos no todo" (Ricoeur, 1950: 443). E, embora não se desista de procurar o universal, já não se pretende uma universalidade abstracta e sim, uma "universalidade assimptótica, que marca uma direcção, um horizonte regulador" (Amorós, 2000: 99). A posição hermenêutica, ao inviabilizar a legitimidade de uma racionalidade total, faz entrar no campo do saber o valor da argumentação, contribuindo para a criação de uma "cultura de razões" e para a defesa da necessidade de se procurarem diferentes lugares de explicação e de compreensão da realidade. Se o ser se pode dizer de muitas maneiras é importante que todas elas interajam entre si de modo a possibilitarem um falar em conjunto que ponha fim a um monolitismo discursivo com fachada de neutralidade universal. ${ }^{2}$ É no contexto da possibilidade e da necessidade das narrativas plurais que entronca a razão específica do sentido deste trabalho e a sua possibilidade de poder reforçar a consciência de si do feminismo.

Judy Chicago criou o Dinner Party para dar figura à nossa herança e ao nosso poder. Na mesma linha, todos os movimentos filosóficos procuraram na história da filosofia lugares onde pudessem mergulhar raízes e encontrar solo legitimador. A filosofia feminista não pode fugir a essa regra, sendo dentro desse esforço que pretendo operacionalizar a ideia gadameriana de consciência histórica no sentido de propor outras e diferentes leituras do passado, procurando re-significar a ideia de que a dominação masculina foi universal e pacificamente aceite, pondo a hipótese de que essa dominação

\footnotetext{
${ }^{1}$ Expressão usada também por Celia Amorós.

${ }^{2}$ Esta racionalidade hermenêutica situa-se entre uma racionalidade moderna e uma racionalidade pós-moderna, aceitando, da primeira, o seu poder discriminador e analítico e o valor da formalização, mas recusando o seu sentido totalizador e excludente, e da segunda, o reconhecimento da finitude e o valor das diferenças.
} 
tenha apenas tido a aparência de ter sido totalmente aceite. Esse percurso de re-significação pode mais uma vez apoiar-se nas seguintes palavras de Gadamer:

A consciência histórica não escuta de forma beatífica a voz que lhe chega do passado mas, reflectindo sobre ela, recoloca-a no contexto em que ela se enraíza para avaliar a significação e o valor relativo que lhe pertence. Este comportamento reflexivo perante a tradição chama-se interpretação. (1996: 24-25, sublinhado meu)

Assim sendo, pertencer a um tempo e a uma cultura significa possuir uma herança, constituída por um conjunto de recursos de interpretação, com a qual nos orientamos como humanos, como se viu. Contudo, tal interpretação deve configurar-se como um comportamento reflexivo perante a herança cultural e não representar uma aceitação passiva dela. Ou seja, "ter sentido histórico" obriga a reconhecer o legado cultural que recebemos, mas, obriga, igualmente, a re-avaliá-lo e a re-interpretá-lo, de tal forma que possamos re-configurar, com maior equidade, a herança cultural que vamos deixar.

No caso das representações do feminino, o trabalho de interpretação do legado cultural é particularmente delicado porque tem de ser feito ao arrepio daquilo que mais profundamente nos constitui, tendo de começar por uma desconstrução e por uma hermenêutica da suspeita, uma vez que as representações do feminino mais enraizadas advêm de uma concepção antropológica assimétrica, que toma o masculino como padrão e o feminino como derivado. ${ }^{3}$ Nesse contexto desconstrutor e de suspeição, um olhar reflexivo sobre a tradição ocidental deve deixar-se orientar pela ideia de que a dominação masculina não foi universal e pacificamente aceite, mas apenas assumiu o aspecto de parecer ter sido absolutamente aceite. Ou seja, re-significar a nossa História comum, de homens e de mulheres, obriga a procurar os ruídos à aceitação universal da dominação masculina que ocorreram e trazer à luz os sinais da ambiguidade e da complexidade nas relações de poder entre os sexos, que todas as épocas testemunham. Sem a desocultação desses acontecimentos não será possível fazer um novo caminho de entendimento do nosso modo de ser e de estar e, nós, mulheres, estaremos desmunidas de figuras femininas que materializem a possibilidade de nos olharmos como seres humanos integrais. Além disso, se aceitarmos passivamente a ideia de que a dominação masculina foi sempre completamente aceite, estamos a fazer uma nova discriminação em relação à nossa herança

${ }_{3}^{3}$ Cf. a este respeito a recolha de Benoite Groult (1993). 
cultural, porque não fazemos justiça a quem se insurgiu contra a dominação do masculino, e estamos, por nossa vez, a invisibilizar o seu esforço, reiterando o legado cultural que o conseguiu escamotear.

Tal interpretação reflexiva da tradição ocidental vai mostrar-nos um modo de pensar as mulheres e o feminino, a que se poderá chamar pensar canónico - que dá das mulheres e do feminino uma visão negativa e subalterna -, mas também uma contracorrente de pensamento ou ruídos marginais ao pensar dominante que evidenciam o facto de a aceitação da dominância do masculino nem sempre ter sido pacífica.

\section{Re-significando saberes velhos}

$\mathrm{Na}$ sua origem, a filosofia fala grego, e essa origem pautou-se por uma recusa e por uma ruptura. Recusa de um certo tipo de saber mítico ou poético e ruptura com o modo de pensar que aquele saber envolvia, situação que Maria Zambrano interpreta designando o discurso filosófico como um discurso ético por corresponder à vontade humana de construir o seu próprio saber, de não o aceitar de qualquer fonte exterior.

Esta dupla situação de recusa e ruptura originou um modo de pensar novo que fundou e determinou a maneira como o ocidente se desenvolveu do ponto de vista epistemológico. Com essa herança veio também o que chamei acima estereótipos arquetípicos, ou discriminações fundadoras acerca do feminino e das mulheres, marcando indelevelmente toda a antropologia posterior, que se desenvolverá em concepções diferentes mas sempre configurando uma assimetria entre as mulheres e os homens. A eficácia histórica dessa herança é de tal modo marcante que Freud, que se contrapôs a quase todos os modos de pensar instituídos, em relação ao feminino e às mulheres limitou-se a reiterar aquilo que Aristóteles tinha definido, porque o complexo de castração e a inveja do pénis mais não são do que a reiteração da perspectiva aristotélica, agora elevada a saber científico. Noutro campo de significações, a ideia lacaniana de que só o falo tem capacidade para evocar um campo simbólico próprio apenas faz ressonância daquilo que, na Grécia, ficou instituído como universal neutro, mas que, de facto, foi assimilado ao masculino.

A filosofia grega é, pois, a nossa herança e o nosso destino. Acolhê-la, na órbita do que ficou dito antes sobre a consciência histórica, obriga, necessariamente a re-significá-la ou, pelo menos, a tentar fazê-lo. Para realizar essa tentativa, proponho uma série de questões orientadoras e respectivas respostas, no horizonte das quais organizarei a segunda parte do meu texto. 


\begin{tabular}{|l|l|}
\hline \multicolumn{1}{|c|}{ Questões } & \multicolumn{1}{|c|}{ Respostas } \\
\hline $\begin{array}{l}\text { O que é que herdámos da Grécia, sem reflec- } \\
\text { tirmos no seu processo de constituição, } \\
\text { tomando-o como natural? }\end{array}$ & $\begin{array}{l}\text { A ideia do universal neutro, com tudo o que } \\
\text { Ihe vem associado }\end{array}$ \\
\hline O que é que recusámos liminarmente? & A proposta platónica \\
\hline O que é que denegrimos ou minimizámos? & $\begin{array}{l}\text { A existência atestada da importância de } \\
\text { algumas figuras femininas, como é o caso de } \\
\text { Safo e de Aspásia }\end{array}$ \\
\hline $\begin{array}{l}\text { O que é que ignorámos ou não aceitámos } \\
\text { como herança? }\end{array}$ & $\begin{array}{l}\text { Alguns insólitos da Cultura Grega, se tivermos } \\
\text { em conta a depreciação do feminino, como } \\
\text { por exemplo: }\end{array}$ \\
$\begin{array}{l}\text { - A importância do feminino na transmissão } \\
\text { do saber - Hesíodo (Teogonia) e Parménides } \\
\text { (Poema) } \\
- \text { A importância da figura feminina na confi- } \\
\text { guração das questões-limite que se põem ao } \\
\text { ser humano, testemunhada pelas tragédias } \\
\text { O inesperado da proposta platónica de pensar } \\
\text { a possibilidade de haver filósofas-rainhas ou } \\
\text { dos exemplos de Lisístrata, de Assembleia de } \\
\text { mulheres e de Melanipa, a filósofa }\end{array}$ \\
\hline
\end{tabular}

No âmbito deste texto não se poderão desenvolver todos os aspectos acima identificados, pelo que me aterei, apenas, a quatro, por serem ou mais conhecidos, ou mais insólitos ou paradigmáticos ou mais determinantes, a saber:

- A questão do universal neutro

- A controvérsia sobre Platão

- O caso de Safo e de Aspásia

- O simbólico de três peças insólitas

\section{Universal neutro/falso neutro}

Celia Amorós, na apresentação de uma colectânea de estudos sobre a conceptualização do feminino na filosofia grega, depois de afirmar que desde muito cedo há uma conceptualização ideológica do feminino que a contrapõe a um suposto universal neutro, diz duas coisas fundamentais:

a. [...] aquilo que é pensado como o genérico humano apresenta-se num plano de abstracção que neutraliza os opostos sexuais [...]. Contudo, não de tal maneira que aquilo que é proposto ao nível da abstracção do neutro possa ser comunicável no 
masculino ou no feminino: constituir-se-á como o masculino, que assumirá, deste modo, o neutro, e assim não se porá a si mesmo como o masculino, e sim como o próprio genérico bumano.

b. Ao ficar do lado do diferente, do outro-diferente-do-neutro, e sendo o neutro o pensado enquanto neutro - e vice-versa, na medida em que se tornará neutro enquanto pensado -, o feminino tornar-se-á o não-pensado. (Sedeño, 1994: vii)

Vou explorar a sua dupla afirmação - a do escamoteamento do processo de assimilação entre universal neutro e masculino e a da transformação do feminino de não pensado em impensável - servindo-me da perspectiva de Zambrano sobre as origens da filosofia grega, nomeadamente a ligação directa que a autora faz entre Filosofia e violência (Zambrano, 1991). Centrada em Platão e em Aristóteles e no quadro da comparação entre filosofia e poesia, Zambrano chama à atitude filosófica um êxtase fracassado por uma cisão porque o filósofo, começando por se extasiar perante o deslumbramento da realidade, ao contrário do poeta que se perde nela, abandona-a, abstrai dela para conquistar, nesse afastamento ascético, a compreensão da sua essência. A imagem que a autora nos dá da origem da filosofia evidencia que o desejo filosófico é o da unidade ou da totalização do saber. Do seu ponto de vista, este querer o todo unificado transforma-se em obsessão e perseguirá a filosofia como um fantasma. Dizer a palavra humana sobre a realidade, em lugar da palavra divina da poesia mítica, vai significar, para o filósofo, dizer uma palavra última, absoluta e pura, comportando, assim, a filosofia uma dupla violência: a da separação do deslumbramento primeiro sobre o real e a da imposição de uma ordem compreensiva a esse mesmo real. Dentro desta interpretação, Zambrano afirma que no mundo grego houve duas possibilidades de o pensamento filosófico se ter desenvolvido - uma ligada a um logos temporal, a via pitagórica, do número e da música, e outra ligada ao logos espacial, da palavra e do ser. ${ }^{4}$

O logos temporal tanto privilegia a palavra como o silêncio, querendo relevar o ritmo e o tempo como modo de ser da realidade. Se tivesse triunfado esta forma de pensar, a razão filosófica teria tido de encontrar uma outra maneira de se expressar. Não foi o caso, porque triunfou o logos aristotélico fazendo prevalecer a teoria da definição e do juízo, definindo e julgando todas as coisas. Com a vitória desta forma logóica ganhou a perspectiva da unidade, da clareza, da luminosidade e o universal abstracto e pretensamente neutro configurou-se como valor supremo. Convém, contudo,

\footnotetext{
${ }^{4}$ Desenvolvi esta ideia em textos anteriores: Fernanda Henriques (1998a, 2001).
} 
saber como é que, no plano antropológico e político, Aristóteles, o ganhador, definiu o Universal.

Numa obra dedicada a este tema, Amparo Moreno separa "sexismo" de "androcentrismo" para mostrar que a concepção herdada da Política de Aristóteles acerca do suposto universal homem não só exclui todas as mulheres, como também muitos homens. Afirma ela que a conceptualização de homem que Aristóteles forjou, nomeadamente no livro I da Politica, referia-se a aner-andros, ou seja, "ao homem feito, a que assumiu os valores próprios da virilidade, crendo-se, por isso, com direito a impor-se sobre outras e outros" (Moreno, 1988: 18).

Perspectivando a sua análise sobre obras académicas de referência que comentam e difundem a perspectiva aristotélica, Amparo Moreno mostra que a transmissão do pensamento aristotélico se faz ou ignorando completamente as remissões de Aristóteles às mulheres, aos escravos e aos estrangeiros, ou minimizando-as, ou, ainda, referindo apenas a posição aristotélica sobre a escravatura. Esta forma de transmitir o pensamento aristotélico serve a ideia de um universal neutro, mas, de facto, ignora a significação discriminadora que o próprio referencial semântico do conceito tinha na origem, porque Aristóteles sabia a quem se aplicava o seu conceito, sabendo quais eram os homens que podiam ser cidadãos da sua polis, mas nós, todo o Ocidente, quando recebemos a ideia aristotélica e usamos o vocábulo homem para nos referirmos à humanidade, estamos a escamotear a dimensão segregacionista que o termo tinha na origem, dando ao discurso académico e ao discurso público aquilo que Moreno chama uma opacidade androcêntrica. Por outras palavras, relegamos para o plano do impensado as condições de constituição do conceito e, ao fazê-lo, naturalizamo-lo, retirando-lhe o seu carácter de construído, apresentando-o como sendo de si mesmo um universal neutro e contribuindo para a difusão de uma ideia de humanidade como devendo ser: viril, combativa, dominadora e possuidora de propriedade.

A importância desta perspectiva liga-se à finalidade última da Política de Aristóteles: conceptualizar a naturalidade de um estado de coisas, nomeadamente evidenciar que a polis representava o modo de organização colectivo natural. Por isso, Aristóteles quer legitimar, com base na "natureza das coisas", quem tem naturalmente o poder de mandar e quem tem, naturalmente, de ser mandado. Por isso, diz, no início do livro I Política, que a natureza criou uns seres para mandar e outros para obedecer, salientando que, desse modo, tudo estaria bem para todos e que, no conjunto, todos ganhariam. A perspectiva aristotélica serviu o Ocidente durante muitos séculos, legitimando a escravatura. Resta perguntar se também continua a servir para a manutenção do afastamento das mulheres da vida pública e 
de um conceito de cidadania pleno e inclusivo. Pelo menos foi a sua sombra que triunfou noutros pensamentos ganhadores, como é o caso de Jean-Jacques Rousseau para quem o lugar das mulheres segundo "a natureza das coisas" era claro:

$\mathrm{Na}$ união dos sexos cada um concorre igualmente para o objecto comum, mas não da mesma maneira. [...] Um deve ser forte, o outro passivo e fraco: é preciso, necessariamente, que um vigie e tenha poder, sendo suficiente que o outro ofereça pouca resistência.

Estabelecido este princípio, deduz-se que a mulher é feita especialmente para agradar ao homem. (apud Henriques, 1998b: 188-189)

Estes e muitos outros exemplos evidenciam que quando se quer instaurar a superioridade de uma parte do conjunto humano sobre outro, há sempre a tendência de "encontrar" uma "natureza das coisas" que o fundamenta, pelo que é crucial estabelecer como objectivo central do pensamento feminista - ou de qualquer outra forma de pensar a favor de um pensamento justo - desocultar o construído e o contexto de construção que se esconde por detrás do que quer apresentar-se a si mesmo como natural. A haver uma palavra de ordem a favor da não discriminação de qualquer tipo ela deveria ser des-naturalizar e, especificamente, em relação à ideia de universal neutro, esta des-naturalização é absolutamente essencial.

\section{A não aceitação da proposta platónica sobre a Cidade Justa}

Não parece ilegítimo considerar que foi a transformação em impensado do contexto da ideia aristotélica de homem-cidadão uma das razões responsáveis pela recepção que teve a proposta de Platão, na República, de que também as mulheres poderiam governar a cidade e ser filósofas-rainhas.

Platão fez duas propostas de organização social e política: a da República e a das Leis. ${ }^{5} \mathrm{Na}$ primeira defende que, embora como grupo, os homens sejam superiores às mulheres, há muitas mulheres melhores que muitos homens e, portanto, deveria dar-se às mulheres a possibilidade de usufruírem de uma educação capaz de as tornar possíveis governantes da cidade. Conhecendo a ideia platónica, de que só quem praticasse a filosofia poderia ser bom governante, a sua proposta para as mulheres, na República, significa que elas, pelo menos algumas, poderiam chegar ao cume do saber, representado pela filosofia, podendo ser rainhas da cidade justa. Mesmo em

\footnotetext{
5 Para esta questão ver, por exemplo: Julie K. Ward (1996); Sister Prudence Allen, R.S.M. (1985); Claude Mossé (1983).
} 
termos de utopia, não parece irrelevante que esta ideia tenha surgido uma vez na Grécia e que seja alvo de argumentação numa das mais conhecidas obras da literatura filosófica ocidental.

Acontece, porém, que essa cultura aceitou como importante a obra, mas excluiu como ridícula, descabida ou contra "a natureza das coisas" a parte da obra onde se defendia a possibilidade dupla do acesso das mulheres ao máximo do saber e do poder. Natalie Bluestone faz a análise da recepção académica desta questão, a partir de 1870, encontrando entre 1870 e 1970, sete tipos de hostilidade em relação à proposta platónica, de que destaco as seguintes quatro:

- A igualdade não é uma temática: desvalorização da proposta

- As mulheres são diferentes: a proposta é não-natural

- As mulheres têm coisas melhores para fazer: a proposta é indesejável

- Platão não quis realmente dizer aquilo: a proposta não é intencional, não é adequada ou é cómica (Bluestone, 1987: 21-73).

Não creio que, do ponto de vista académico, se possa ficar indiferente perante tais argumentos para não aceitar uma proposta teórica. Não creio também que ela não tenha tido uma decisiva eficácia bistórica na formação da nossa consciência colectiva e que não seja ela que ainda hoje trabalha nas costas de cada uma e de cada um quando tem dúvidas sobre a paridade ou sobre o valor das quotas como processo de discriminação positiva, funcionando activamente como esquema pré-compreensivo.

A quebra que Bluestone introduz na sua análise da recepção da proposta platónica nos anos 70 do século Xx prende-se, como é óbvio, com a revolução cultural e epistemológica que os anos 60 e 70 introduziram no imaginário colectivo e que, de uma ou outra maneira, teve alguns reflexos na Academia. Contudo, se bem que a autora reconheça diferenças na recepção do tema posteriormente a esse marco, não deixa de identificar a persistência do estereótipo, sendo de realçar a leitura de Allan Bloom que continua a manter uma interpretação eminentemente sexista da proposta platónica (Bluestone, 1987: 154 ss.). No quadro analítico feito por Bluestone, fica claro que é a recepção de Platão que continua a apagar o sentido e a pertinência da proposta do velho filósofo grego que, embora considerasse que as mulheres eram "almas caídas", foi capaz de conceptualizar o feminino sem o tomar como um colectivo e, assim, conceber como inteligível que pelo menos algumas mulheres poderiam ascender ao governo da cidade.

Sem querer fazer de Platão defensor das mulheres, é necessário tomar consciência do que está em causa na proposta platónica: uma argumentação 
racional a favor do direito humano e da legitimidade filosófica de as mulheres poderem ascender ao saber maior e, em consequência, ao poder maior. Se tivermos em linha de conta que mesmo nos dias de hoje esses direitos ainda não são pacificamente aceites, poderemos ter consciência de quão longe foi a ousadia platónica.

\section{Minimizar, denegrir e ridicularizar as mulheres notáveis do Mundo Antigo}

$\mathrm{Na}$ mesma linha de pensamento que tenho vindo a desenvolver, parece igualmente possível considerar o androcentrismo, sob a capa de universal neutro, como um factor importante do silenciamento ou da minimização das mulheres que, apesar de toda a invisibilização, não foi possível fazer desaparecer da história das ideias e da cultura. Sobretudo os casos de Safo e Aspásia podem ser tomados como paradigma da ocultação do feminino para fazer crer, deliberada ou inconscientemente, que as mulheres sempre se limitaram ao gineceu e que a dominância do masculino foi universal, pacífica e "segundo a natureza das coisas".

A recepção de Safo e Aspásia tem em comum o facto de ambas serem articuladas com a questão da sexualidade; contudo, tem também diferenças que se prendem com o que pode ter sido a sua história pessoal e os tópicos pelos quais adquiriram relevância.

Safo tem duas associações imediatas no imaginário corrente: $10^{\mathrm{a}}$ musa e lésbica. Em nenhum dos casos se atende à especificidade que a tornou impossível de apagar da história: ter sido uma das grandes poetas de todos os tempos. Safo seria de Mitilene, cidade de Lesbos, a sua vida terá decorrido entre a segunda metade do século VII e as primeiras décadas do século VI a.C., sendo, por isso, ligeiramente posterior a Hesíodo e a Simónides, poetas que deram do feminino visões bastante pouco positivas.

Segundo os estudos especializados, a informação sobre a vida de Safo é tão contraditória que é a própria obra da autora que fornece melhores indicações sobre ela, permitindo conceber que era responsável por si e pelo seu círculo familiar, estando muito longe da ideia feita da mulher grega, confinada ao lar e com tutela (Iriarte, 1997). Um dos preconceitos que a recepção da poesia de Safo parece não ter conseguido superar foi o acantonamento da sua poesia a uma interioridade e a um sentimentalismo enclausurado num Eros auto-contemplativo que é posto, habitualmente, em confronto com a consciência cidadã de Alceo, com quem partilhou a pátria e a época, mas que cantava a guerra e a vida activa. Como dizem alguns estudos, este preconceito tende a tornar simbólica a própria figura de Safo, relegando-a para o plano do divino ao identificá-la como "a musa mortal". 
O outro preconceito diz respeito à própria vida de Safo, referindo-se à sua assimilação com o lesbianismo, nome, aliás, recolhido da sua ilha natal.

Esta situação é significativa do quadro ideológico em que as mulheres são conceptualizadas, porque, assentando a sua reputação de lésbica nas relações que mantinha com o seu círculo de alunas, representa transformar a interpretação de uma situação educacional comum na Grécia, como se fosse uma especificidade e, por outro lado, essa interpretação, transformando-se no seu avatar, não corresponde ao modo como essa ideia se liga com outras figuras notáveis da Grécia, como é o caso de Sócrates, cuja apresentação nunca começa a partir da sua paixão por Alcibíades. ${ }^{6}$ Contudo, no contexto da mundivisão e da moral comum ocidental, relacionar uma figura notável à homosexualidade era uma forma de a denegrir e, portanto, de obscurecer o seu valor. Deste modo, a recepção de Safo representa o protótipo da imagem dominante das representações míticas do feminino: ou divina ou malvada.

Quanto a Aspásia, ${ }^{7}$ a maior parte das pessoas para quem o seu nome tem algum significado associam-na à sua relação amorosa com Péricles, de quem foi amante. Saberão, certamente, também, que ela tinha uma grande influência nele, nomeadamente, para as coisas negativas, mas, de um modo geral, não se associará Aspásia a um círculo de elite intelectual de Atenas, onde ela pontificava como os homens notáveis que também o integravam, evidenciando com a sua existência que havia, em Atenas, outras maneiras de se ser mulher sem ser a de esposa fiel e submissa de qualquer ateniense, garantindo através dessa fidelidade e submissão a honra do nome e a posse dos bens. Este olhar global e generalizado sobre Aspásia testemunha do mesmo ideologismo interpretativo que se encontrou em Safo, mostrando que quando não é possível ignorar as mulheres divulga-se delas aquilo que é mais desprestigiador aos olhos de uma moral, também ela apenas, pretensamente, neutra.

O estudo introdutório à edição bilingue de uma obra sobre Aspásia termina de uma forma lapidar para o meu propósito:

[...] as informações platónicas sobre Aspásia respondem à realidade histórica. Considero que esta é a melhor hipótese para explicar o que os críticos chamam reiteradamente o "mistério" ou o "enigma" de Menexeno. O motivo pelo qual a imensa maioria de autores modernos e alguns antigos não só não aceitam essa hipótese como nem sequer a consideram digna de estudo é já outra questão que nos levaria a temas fundamentais da história ideológica do Ocidente. (Dueso, 1994: XL-XLI)

\footnotetext{
${ }^{6}$ E se o que está em causa é o facto de Sócrates ter sido casado, também a Safo é atribuído um marido e uma filha e, além de tudo, ela compôs epitalâmios, ou seja, cânticos de boda.

7 Sobre Aspásia ver, por exemplo: Mary E. Waithe (1992); Amalia G. Suárez, (1997); José S. Dueso (1994).
} 
É interessante que seja, de novo, a recepção de Platão que esteja no cerne da controvérsia; no caso trata-se do diálogo Menexeno, onde Aspásia aparece referida como mestre de retórica e autora de discursos.

Segundo Mary E. Waithe (1992), os comentadores desta obra de Platão dividem-se em dois grandes grupos: o que considera que o Menexeno pertence ao corpo das obras platónicas, mas é a sua única obra não filosófica, desprestigiando-a, portanto; e o grupo que considera que o que se diz na obra em relação a Aspásia é da própria Aspásia, e que Platão o escreve porque reconhece a reputação dela como filósofa/retórica, deixando, clara a sua desaprovação em relação à influência que os filósofos como ela tinham na Grécia.

Para Dueso - autor da citação acima referida -, que pertence a este segundo grupo, as palavras de Platão sobre Aspásia demonstram a importância que ela teria nos círculos respectivos. Na sua argumentação, Dueso põe a claro um aspecto decisivo, referindo que, a não se tomar como fundado nos factos o que Platão diz sobre Aspásia, estar-se-ia a usar um critério diferente daquele que se utiliza habitualmente na recepção da obra de Platão, nomeadamente no caso de Lisias, no Fedro, de Górgias e de Protágoras em vários diálogos platónicos.

Na sua obra sobre Aspásia, o autor reúne 34 testemunhos, 17 dos quais referem a perícia retórica de Aspásia e outros a sua ligação à filosofia, pelo que considera absolutamente legítimo pensar que Aspásia esteve ligada à filosofia e à arte de argumentar, salientando que o processo de impiedade que foi movido contra ela só testemunha da sua importância e da sua relevância intelectual. Dueso põe mesmo a hipótese de que em redor de Péricles e do seu círculo se tenha desenvolvido um movimento de emancipação feminina que, segundo a sua leitura, ajudaria a explicar não só o processo de Aspásia, mas também comédias como Lisístrata e Assembleia de mulheres.

\section{Alguns insólitos da cultura grega}

As referências a Lisístrata e a Assembleia de mulberes conduzem ao último ponto deste trabalho: analisar alguns insólitos da herança grega, nomeadamente, a existência de três peças de teatro, duas comédias e uma tragédia, onde as mulheres são protagonistas em situações totalmente inverosímeis no quadro da conceptualização dominante do feminino.

Contudo, para legitimar esta incursão pelo poético chamo em minha defesa as palavras que abrem a segunda parte da obra $A$ mulher na Grécia clássica:

Não se conhece uma sociedade apenas pelos factos jurídicos, sociais e económicos. Com muita frequência, esta sociedade se mostra com muito mais nitidez através da imagem que faz e dá de si mesma, do que através das estatísticas ou das leis, por muito 
estáveis que sejam. [...] Por conseguinte, um estudo da mulher na Grécia implica pôr em dia as imagens que os próprios gregos criaram e plasmaram na epopeia, na poesia lírica, no teatro trágico e cómico, sem pôr de lado as opiniões dos filósofos e as narrativas dos historiadores. (Mossé, 1990: 105-106)

Embora não esteja de acordo com as conclusões que a autora vai retirar da sua análise, partilho do seu ponto de partida acerca da importância do que se poderia designar por imaginário social e que a literatura e o teatro tão bem protagonizam. Nessa medida, chamo à colação o papel das mulheres em todo o teatro grego e penso que há qualquer coisa que quer ser dita através do protagonismo das mulheres no imaginário teatral da antiguidade clássica, através de quem são elaborados e discutidos os problemas base da reflexão filosófica. Numa obra fundamental na produção teológica feminista - Em memória d'Ela -, Elisabeth Fiorenza (1986) propõe-se, como especialista em exegese neotestamentária, reconstruir a história dos princípios do cristianismo através da configuração do seu Sitz im Leben, isto é, do contexto global da sua emergência, mostrando as condições sociais, culturais e ideológicas da produção dos textos para os poder arrancar a um valor simbólico absoluto e, assim, enquadrá-los temporalmente, separando o simbólico do histórico.

A meu ver, o teatro grego necessita de uma operação reflexiva oposta a esta para tornar visível que há um contradição entre o seu Sitz im Leben e o papel das mulheres nos testemunhos textuais que chegaram até nós, sendo necessário explorar a função simbólica dessa contradição. Nesse sentido, ao contrário do que Fiorenza fez para o cristianismo primitivo, o teatro grego deve ser analisado no interior do seu Sitz im Lebem - fortemente patriarcal - para, pelo menos, pôr como hipótese que havia ruídos ao pensamento dominante, que nem toda a gente pensava da mesma maneira e que, portanto, a dominação masculina não era pacificamente aceite.

Do complexo de questões que avultam, neste contexto, gostaria de destacar duas situações que parecem mais facilmente exemplares:

- A ligação das mulheres a problemas sociais graves - a paz e a vivência colectiva - como é o caso de Lisístrata e Assembleia de mulheres. ${ }^{8}$

- O totalmente inusitado da existência de uma peça cujo título é Melanipa, a filósofa.

\footnotetext{
${ }^{8}$ Lisístrata (411 a.C.) - recomeço da guerra entre Atenas e Esparta - a Ateniense Lisístrata convoca as mulheres da Grécia para se mobilizarem e porem fim à guerra, fazendo uma greve de sexo. Assembleia de mulheres: as mulheres atenienses disfarçadas de homens, Praxágora como chefe, tomam conta do poder e instauram um regime comunista.
} 
O estudo acima referido de Claude Mossé retira a ambas as comédias de Aristófanes qualquer significado político, considerando que quer Lisistrata quer Assembleia de Mulheres apenas põem em cena figuras femininas com todas as características tradicionalmente adscritas às mulheres, especialmente as negativas, fazendo propostas estritamente ligadas à mundivisão feminina. ${ }^{9}$ Como se viu antes, Dueso propõe outra leitura: a de que essas comédias estivessem a fazer ressonância de uma contestação de mulheres, no âmbito do círculo de Péricles.

Não quero, nem poderia, dirimir este confronto interpretativo; contudo, como leitora, não posso deixar de dizer que é notável que Aristófanes tenha escolhido desenvolver uma intriga com protagonistas femininas a propor soluções políticas em situações de crise e que, em ambos os casos, tais figuras femininas tenham conseguido mobilizar-se, organizar-se e ocupar o espaço público que, teoricamente, lhes estava vedado. Seja o que for que se queira pensar, é forçoso pôr uma de duas hipóteses: ou o próprio Aristófanes pensou por si mesmo a possibilidade que encenou - o que significa reconhecer que as mulheres poderiam desempenhar tais papéis - ou, então, fez-se eco de outros ou outras que assim pensavam. Em qualquer dos casos, parece assinalável que a força, o poder e a capacidade de mobilização e de acção pública das mulheres tenha sido posta em cena na Grécia do século v e tenha sido aplaudida pelos gregos. Por outro lado, o facto de as soluções propostas pelas mulheres serem originárias da experiência e da mundivisão femininas só lhes retira valor efectivo se essa solução for avaliada a partir da perspectiva de que apenas as soluções do mundo e da vivência masculina são eficazes e adequadas. Ora, acontece que em qualquer dos exemplos citados as ditas soluções masculinas tinham-se esgotado e gerado o caos, sendo legítimo que se procurassem alternativas.

Melanipa, a filósofa é o título de uma tragédia de Eurípedes de que apenas nos chegaram alguns fragmentos. O título da peça corresponde ao seu conteúdo porque põe em cena uma mulher filósofa ou, pelo menos, uma mulher que filosofa. A história é a seguinte: seduzida por Poseidon, Melanipa teve dois gémeos. Com medo de seu pai Éolo e por ordem do deus, pôs os filhos num estábulo. Descobertos os gémeos e levados a Éolo, este, considerando-os monstros, condenou-os a serem queimados vivos. Melanipa intervém,

\footnotetext{
${ }^{9}$ No caso de Lisístrata as mulheres propõem a substituição das armas pela roca e pelo fuso. "Porém", acrescenta ainda a autora, "o espectador ateniense do século v sabia muito bem que no final tudo voltaria à normalidade, que o mundo que estava 'do avesso' ficaria direito de novo e que as mulheres encontrariam outra vez o caminho da casa” (132). Na Assembleia de mulheres, as protagonistas concebem a vida da cidade em termos de um imenso Oikos, não saindo, portanto, do imaginário feminino.
} 
demonstrando, através de argumentos racionais, que as crianças não poderiam ser monstros e teriam de ter uma mãe humana e, finalmente, acaba reconhecendo ser ela a mãe. O pai cega-a e enclausura-a, mas decorridos 16 anos será libertada pelos filhos e pelo próprio pai, recuperando a vista.

Séverine Auffret (1988) dedica um estudo a esta obra, do qual retirarei algumas notas interpretativas:

- Começando com a exploração do significado do nome da protagonista, Melanipa, que remete para égua negra, a autora interpreta-o como sendo o aspecto feminino e trágico do Centauro Quíron, antepassado dos filósofos, por protagonizar o domínio do espírito sobre a potência e a força animal que controla e subsume. Neste contexto, para Séverine Auffret o trágico de Melanipa poria em cena não apenas a situação grega, mas o paradigma da relação entre as mulheres e a Filosofia: ficarem sempre à sua margem e nas suas margens. A este respeito evoca a obra de Gilles Ménage, Historia mullierum philosopharum, onde se identificam 65 nomes de mulheres filósofas, o que prova também que é na recepção e na divulgação do pensamento ligado ao feminino e às mulheres que se faz um ocultamento dessas heranças impedindo-se, portanto, a sua eficácia histórica.

- No âmbito desse ocultamento, ou ilegitimação, Séverine Auffret refere o comentário de Aristóteles na Poética a este respeito, onde se diz que Melanipa é um exemplo de mau gosto teatral porque a personagem não é conveniente, uma vez que é inverosímil que uma jovem desenvolva um discurso filosófico.

- Por fim, numa apreciação da figura de Eurípedes, a autora, salientando o facto de a tragédia acabar bem, embora Melanipa filosofasse, considera que Eurípedes quis pôr em cena, simultaneamente, a proibição de filosofar que pesa sobre as mulheres e os motivos que as devem levar a filosofar.

Mesmo sem entrar na discussão, a meu ver extemporânea, da possível veia pré-feminista de Eurípedes, não se pode ignorar que ele escreveu esta peça e que essa situação tem de ter um significado no âmbito da representação das mulheres e das suas capacidades no mundo grego.

\section{Concluindo}

Sendo apenas uma pequena introdução a um vasto problema, os elementos acima mencionados representam demasiada agitação no pensar dominante para se poder considerar liminarmente a situação das mulheres na Grécia apenas segundo o ângulo da dominação e da irrelevância cultural. 
Um levantamento mais sistemático e aprofundado mostraria, certamente, um maior colorido de perspectivas e uma nova lista de nomes para lá dos velhos conhecidos da literatura canónica. Urge desenvolver entre nós incursões no terreno da filosofia e da cultura grega para "desocultar algumas possibilidades não desenvolvidas do passado" e, assim, aprender a narrar de outra maneira as nossas raízes.

\section{Referências bibliográficas}

Amorós, Celia (2000) (org.), Feminismo y filosofia. Madrid: Síntesis.

Allen, Sister Prudence R.S.M. (1997), The Concept of Woman. The Aristotelian Revolution 750 B.C. - A.D. 1250. Grand Rapids, Mich.: W.B. Eerdmans [11985: Montreal, Eden Press]. Auffret, Sévérine (1988), Melanipe la philosophe. Paris: Maison des Femmes.

Bluestone, Natalie H. (1987), Women in Ideal Society. Oxford/Hamburg/New York: Berg Publ. Lted.

Dueso, José Solana (1994) (trad. e org.), Aspasia de Mileto. Testemonios y discursos. Barcelona: Anthropos.

Fiorenza, Elisabeth (1986), En mémoire d'elle. Paris: E. du Cerf.

Gadamer, Hans-Georg (1996), Le problème de la conscience historique. Paris: Seuil, [11958]. Groult, Benoîte (1993), Cette mâle assurance. Paris: Albin Michel.

Henriques, Fernanda (1998a), "A penumbra tocada de alegria: a razão poética e as relações entre a filosofia e a poesia em María Zambrano”, Philosophica, 11, 49-61.

Henriques, Fernanda (1998b), "Rousseau e a exclusão das mulheres de uma cidadania efectiva", in Maria Luísa R. Ferreira (org.), O que os filósofos pensam sobre as mulheres. Lisboa: CF-UL, 171-190.

Henriques, Fernanda (2001), "María Zambrano e as metáforas do coração", in Aavv, Poiética do Mundo. Lisboa: Colibri, 621-631.

Iriarte, Ana (1997), Safo. Madrid: Ed. del Orto.

Irigaray, Luce (2003), "Poder do discurso, subordinação do feminino", ex aequo, 8, 45-55. Moreno, Amparo (1988), La otra "politica de Aristóteles. Barcelona: Icaria.

Mossé, Claude (1990), La mujer en la Grecia clásica. Madrid: Nerea, [1983, ed. francesa].

Ricoeur, Paul (1950), Le volontaire et l'involontaire. Paris: Aubier-Montaigne.

Sedeño, Eulalia Pérez (1994) (org.), Conceptualización de lo femenino en la filosofia antigua. Madrid: Siglo XXI.

Suárez, Amalia González (1997), Aspasia. Madrid: Ed. del Orto.

Waithe, Mary Ellen (1992) (org.), A History of Women Pbilosophers, 1. Dordrecht: Kluwer Academic Publ.

Ward, Julie K. (1996) (org.), Feminism and Ancient Philosophy. New York and London: Routledge.

Zambrano, María (1991), El hombre y lo divino. Madrid: Ed. Siruela. 